IRA-International Journal of Education \& Multidisciplinary Studies

ISSN 2455-2526; Vol.04, Issue 01 (2016)

Institute of Research Advances

http://research-advances.org/index.php/IJEMS

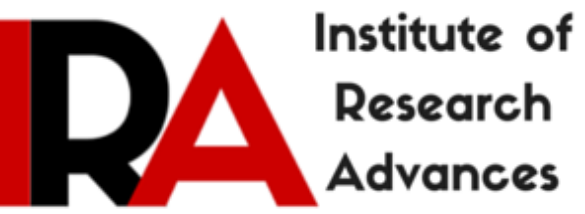

\title{
Organizational Climate of Teacher Education Institutions in West Bengal in relation to Teacher Educators' Motivation to Work
}

\author{
Mr. Madhab Ghosh ${ }^{1}$ \\ Ph.D. Scholar in Education, Ramakrishna Mission Sikshanamandira, \\ Belur Math, Howrah, West Bengal, 711202, India. \\ Dr. Abhijit Guha ${ }^{2}$ \\ Associate Professor, Ramakrishna Mission Sikshanamandira, Belur Math, \\ Howrah, West Bengal, 711202, India.
}

DOI: http://dx.doi.org/10.21013/jems.v4.n1.p15

\section{How to cite this paper:}

Ghosh, M., \& Guha, A. (2016). Organizational Climate of Teacher Education Institutions in West Bengal in relation to Teacher Educators' Motivation to Work. IRA International Journal of Education and Multidisciplinary Studies (ISSN 2455-2526), 4(1). doi:http://dx.doi.org/10.21013/jems.v4.n1.p15

(C) Institute of Research Advances

\section{(c) EY-NO}

This works is licensed under a Creative Commons Attribution-Non Commercial 4.0 International License subject to proper citation to the publication source of the work.

Disclaimer: The scholarly papers as reviewed and published by the Institute of Research Advances (IRA) are the views and opinions of their respective authors and are not the views or opinions of the IRA. The IRA disclaims of any harm or loss caused due to the published content to any party. 


\begin{abstract}
The organizational climate has played a crucial role in an organization/institution resulting in high individual, organizational performance and specially motivation to work. Motivation is the process of stimulating people to action and to achieve a desired task and healthy organizational climate in an individual's expressed career related goals or choices. The organizational climate is very much related with motivational aspects. Teacher educators play an important role in bringing about social transformation leading to national reconstruction. The quality of teachers and inputs, therefore become of paramount importance in the whole process of teaching and learning that are influenced by the organizational climate. 221 teacher educators were randomly selected for the study from West Bengal. Organizational Climate Inventory by Chattopadhyaya and Agarwal (2011) and self developed Teacher Educator's Motivation to Work Scale (2016) was used in the study. It was revealed that the perception of male, self financed and organizational climate of rural teacher educator's are better than the female, government and urban teacher educators. The female; government and urban teacher educators are highly motivated than the male; self finance and rural teacher educators on their work. There was no positive significant relationship between organizational climate as perceived by teacher educators and motivation to work of teacher educators.
\end{abstract}

Keywords: Organizational Climate, Motivation to Work, Teacher Education Institutions, Teacher Educators.

\title{
Introduction:
}

Teacher education institutions are undergoing an over hauling change in the perspectives of quality education. Our nation always struggling for quality with quantity and equity in every sphere of education and teacher education is not the exception. There is a common notion that rapid growth in educational institutions at college and university levels over the years has resulted in the dilution of quality and standard, which in turn has affected the quality of human resource. Organizational climate is generally defined as a psychological state strongly affected by organizational conditions, such as systems, structure and managerial behaviour. An organization is a group of people intentionally organized to accomplish an overall common goal or act of goals. An organization operates according to an overall purpose or mission (Kaur \& Kaur, 2015, p. 56). It includes the leadership focus, authority and responsibility, resource policies and planning and implementation. The organizational climate of an institution is intimately connected with teachers' attitude and behavior. High performance organizations tend to make optimal use of everyone's capabilities which affect their dedication, motivation to timework, job satisfaction and efficacy. Organizational climate describes the members' perception of their work environment. The characteristics of organizational climate are considered as important construct that can change over time, perceived by and shared among organization's members resulting in consensus among individuals. Motivation to work is a human state where competence to work and 'will to work' fuse together. Teachers play a very important role in the learning process. So the teaching motivation of the teacher directly affects the students. If the teacher is not motivated towards teaching, he/she will not be able to motivate the student towards learning. Motivation helps the teacher to teach the student effectively as per their needs (Davidson, 2007).

Litwin \& Stringer (2001) defined that organizational climate as a group of measurable characteristics that member could perceive directly or indirectly in the work environment and as a description of environmental factors, it could help researchers ascertain the effects of environment on employee motivation. Giri and Kumar (2007) acknowledged in an investigation that organizational climate had a significant effect on job satisfaction and work motivation. Ladyong's (2014) findings have 
implications on the role of administrators particularly in enhancing a positive school climate in order to motivate teachers to improve their work performance.

This study would gain significance in the following aspects -

- The study would help to understand the status of organizational climate as perceived by the teacher educators in Teacher Education Institutions (govt./govt. aided and self financed) of West Bengal.

- The study would help to understand the level of motivation to work of teacher educators.

- The study would help to understand the relationship between the organizational climate and motivation to work of teacher educators in Teacher Education Institutions.

In order to assess the organizational climate of teacher education institutions perceived by the teacher educators and motivation to work of teacher educators, a noble attempt was made by the investigators to investigate different aspects which promote status of organizational climate and motivation to work and the nature and level of their motivation now endowed with the teacher educators of West Bengal. The problem for investigation has been stated as "Organizational Climate of Teacher Education Institutions in West Bengal in relation to Teacher Educators' Motivation to Work".

\section{Objectives}

The present study has been designed with the following objectives in mind.

I. To find out the status of organizational climate as perceived by the teacher educators in Teacher Education Institutions.

II. To study teacher educators' level of motivation to work in the Teacher Education Institutions.

III. To study the organizational climate as perceived by teacher educators in teacher education institutions due to categorical variables like gender (male \& female), type of management (govt. \& self financed) and locale (urban \& rural).

IV. To study the level of motivation to work of teacher educators in teacher education institutions due to the categorical variables like gender (male \& female), type of management (govt. \& self financed) and locale (urban \& rural).

V. To study the relationship between organizational climate as perceived by teacher educators with teacher educators' motivation to work in Teacher Education Institutions.

\section{Hypotheses}

Basing upon the objectives stated above, the following hypotheses have been formulated.

$\mathbf{H}_{\mathbf{0}} \mathbf{1}$ : There is no significant difference in the organizational climate as perceived by teacher educators in relation to gender (male and female) variation.

$\mathbf{H}_{\mathbf{0}}$ 2: There is no significant difference in the organizational climate as perceived by teacher educators in relation to type of management (government and self financed) variation.

$\mathbf{H}_{0} 3$ : There is no significant difference in the organizational climate as perceived by teacher educators in relation to locale (urban and rural) variation.

$\mathbf{H}_{\mathbf{0}}$ 4: There is no significant difference in motivation to work of teacher educators in relation to gender (male \& female) variation.

$\mathbf{H}_{0}$ 5: There is no significant difference in motivation to work of teacher educators in relation to type of management (government and self financed) variation.

$\mathbf{H}_{0} \mathbf{6}$ : There is no significant difference in motivation to work of teacher educators in relation to locale (urban and rural) variation. 
$\mathbf{H}_{\mathbf{0}}$ 7: There is no significant relationship between organizational climate as perceived by teacher educators and teacher educators' motivation to work.

\section{Operational Definition of the Terms Used}

Organizational Climate refers to the interpersonal relations in a living organization, member's perception, member's attitude and behavior. It is the collective perception of behavior in an institution. It also refers to its internal environment perceived by its member's means teacher educators (Chattopadhyay and Agrawal, 1976). Motivation to Work here refers to work that is defined as a task, duty or accomplishment. Motivation to work is a human state where competence to work and "will to work" fuse together. Work motivation in the present study refers to the process, which is used to encourage and inspire teachers to perform their jobs efficiently and also to initiate work-related behavior among them. Teacher Educators here refers to those teachers who teach and work at B.Ed. colleges. Teacher Education Institution here refers to the teacher education colleges for the secondary level, which provide B.Ed. course and are either govt./govt. aided or self financed college.

\section{Scope and Delimitation}

The scope of the study is to assess the organizational climate of teacher education institutions and motivation to work of teacher educators in relation to gender, type of management and locale variations. The study was delimited to 221 teacher educators working in different teacher education institutions of West Bengal only.

\section{Methodology}

Design: This study was mainly a descriptive survey design. A descriptive method of research of expost facto type has been adopted for the study. Sample: The population of the study includes all teachers of all the teacher education institutions of West Bengal. A sample of 221 teacher educators had been selected by random sampling procedure from $36 \mathrm{~B}$.Ed. colleges of West Bengal. The sample comprises of male $126(57 \%) \&$ female $95(43 \%)$ ), teachers of govt./govt. aided college $99(45 \%) \&$ teachers of self -financed college $122(55 \%)$ ), and teachers of urban college $100(45 \%) \&$ teachers of rural college 121 (55\%). Tools Used: The Organizational Climate Inventory (OCI) by Chattopadhyaya and Agarwal (2011) was used for the status of organizational climate of teacher education institutions. Reliability co-efficient by Spearman-Brown Formula was 0.898 which shows that there was high internal consistency in the instrument and hence it was highly reliable. In the present study reliability of the scores was computed by using Cronbach's Alpha and was found to be 0.714 for OCI. And self developed Teacher Educator's Motivation to Work Scale (TEMWS,) was used for the study. The reliability calculated for the 23 items of the Teacher Educator's Motivation to Work Scale using Cronbach's alpha was found to be high i.e. 0.854. This indicated that the tool was highly reliable. Procedure: Quantitative data analysis procedure was followed for this study. The collected data were analyzed through IBM SPSS 22.0 version and the significance of ' $t$ ' values were tested at 0.05 level of significance. The Statistical techniques such as mean, SD, $t$ - test and ' $r$ ' test were used in this study.

\section{Results and Discussion}

\section{Testing Objective 1}

\section{Status of the Organizational Climate as Perceived by Teacher Educators}

For the study of status of organizational climate of teacher education institutions as perceived by teacher educators, percentiles were calculated and subsequently categorization of the group were identified on the basis of corresponding percentiles scores which helped the researcher to have an idea about the status of organizational climate as perceived by the teacher educators in teacher education institutions. On the basis of the percentile scores the groups has been divided into three categories which are presented in the following table $\mathbf{1}$ and graphically presented in a figure (i). 


\section{Table 1}

Status of Organizational Climate as Perceived by the Teacher Educators in Teacher Education Institutions

\begin{tabular}{|l|l|l|l|l|}
\hline Percentiles & Raw Scores & $\begin{array}{l}\text { No. of } \\
\text { Sample }\end{array}$ & $\begin{array}{l}\text { \% of } \\
\text { Sample }\end{array}$ & $\begin{array}{l}\text { Status of Organizational } \\
\text { Climate }\end{array}$ \\
\hline $\mathbf{P}_{75}$ \& Above & 229 \& Above & 54 & 24 & High \\
\hline $\mathbf{P}_{25}$ to $\mathbf{P}_{75}$ & 207 to 228 & 108 & 49 & Average \\
\hline $\mathbf{P}_{25}$ \& Below & 206 \& Below & 59 & 27 & Low \\
\hline Total & $\mathbf{2 2 1}$ & $\mathbf{1 0 0}$ & \\
\hline
\end{tabular}

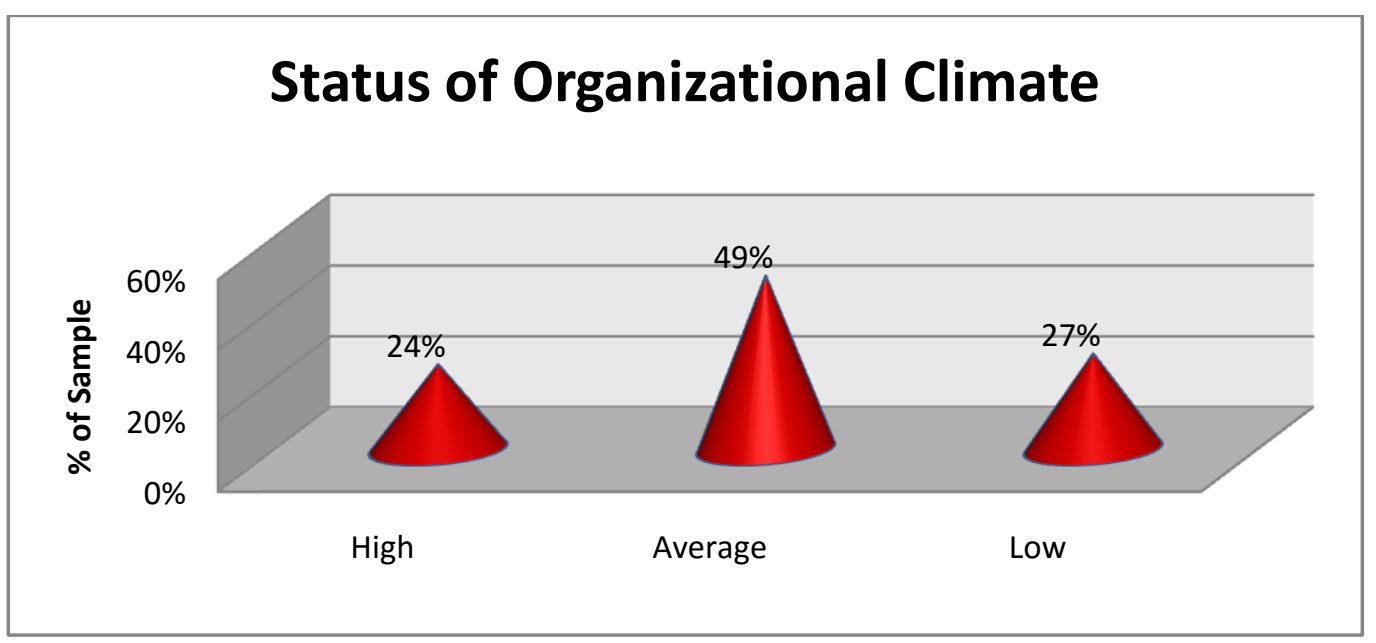

Fig. (i) Bar Graph showing Status of Organizational Climate as Perceived by Teacher Educators

On the above table 1 and figure (i) shows that 24\% (54) and $49 \%$ (108) of teacher educators' perception about organizational climate is High and Average respectively while, 27\% (59) perceive that the organizational climate in teacher education institutions is Low.

\section{Testing Objective 2}

To achieve this objective, data was analyzed and percentiles were calculated to identify and categorize the motivation to work of teacher educators.

\section{Level of the Motivation to Work of Teacher Educators}

For study the level of motivation to work of teacher educators were calculated percentiles and according to that total no of sample and percentage of sample has been divided into three groups in table 2 and graphically presented in a figure (ii). 
Table 2

Teacher Educators' Level of Motivation to Work in Teacher Education Institutions

\begin{tabular}{|l|l|l|l|l|}
\hline Percentiles & Raw Scores & $\begin{array}{l}\text { No. of } \\
\text { Sample }\end{array}$ & $\begin{array}{l}\text { \% of } \\
\text { Sample }\end{array}$ & $\begin{array}{l}\text { Level of Motivation to } \\
\text { Work }\end{array}$ \\
\hline $\mathbf{P}_{75}$ \& Above & 105 \& Above & 51 & 23 & High \\
\hline $\mathbf{P}_{25}$ to $\mathbf{P}_{75}$ & 86 to 104 & 110 & 50 & Average \\
\hline $\mathbf{P}_{25}$ \& Below & 85 \& Below & 60 & 27 & Low \\
\hline Total & & $\mathbf{2 2 1}$ & $\mathbf{1 0 0}$ & \\
\hline
\end{tabular}

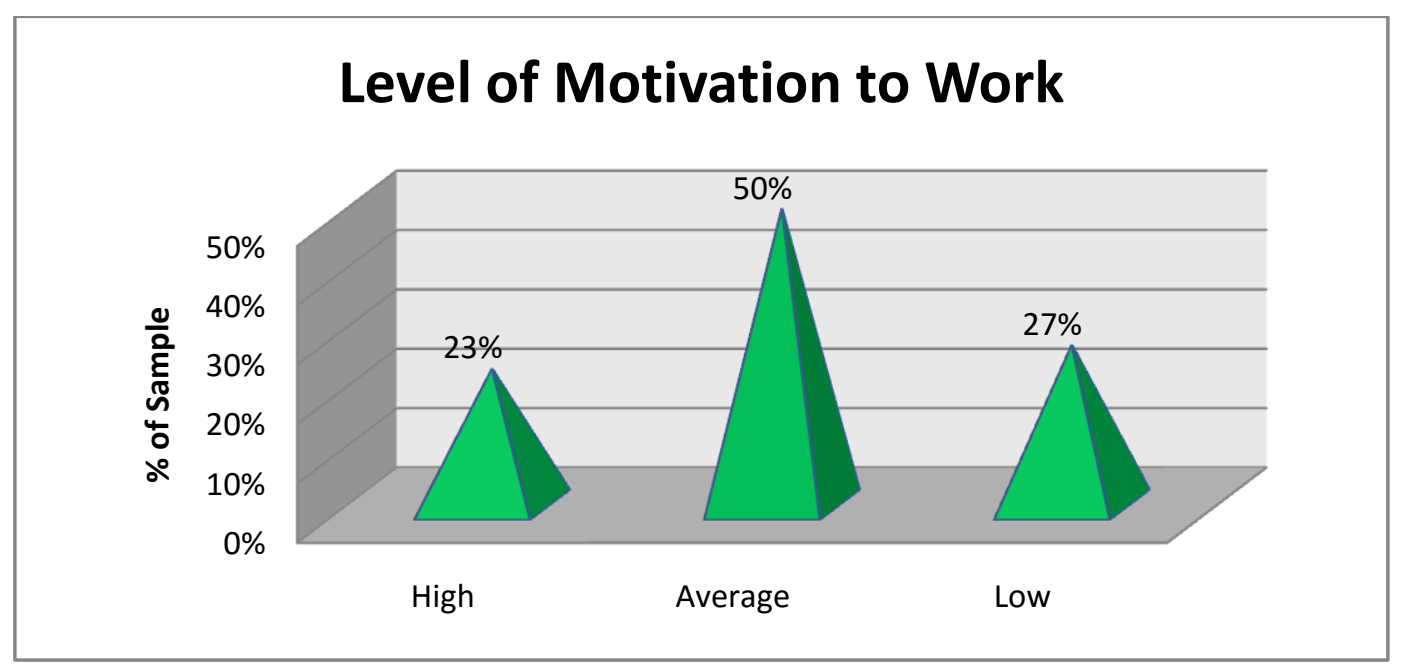

Fig. (ii) Bar Graph showing Teacher Educators' Level of Motivation to Work

On the above table 2 and figure (ii) shows that the 23\% (51) and 50\% (110) teacher educators' level of motivation to work is High and Average respectively while $27 \%$ (60) of teacher educators' level of motivation to work are Low in teacher education institutions.

\section{Testing of Objective 3}

To fulfill this objective, the following null hypotheses $\mathbf{H}_{0} \mathbf{1}, \mathbf{H}_{0} \mathbf{2} \& \mathbf{H}_{0} \mathbf{3}$ were formulated and tested.

\section{Testing Hypotheses $\mathrm{H}_{0} 1$ to $\mathrm{H}_{0} 3$}

Table 3

Group Statistics of Organizational Climate as Perceived by Teacher Educators_Gender, Type of Management and Locale

\begin{tabular}{|l|l|l|l|l|l|l|}
\hline & \multicolumn{2}{|l|}{ Variations } & $\mathbf{N}$ & Mean & $\begin{array}{l}\text { Std. } \\
\text { Deviatio } \\
\text { n }\end{array}$ & $\begin{array}{l}\text { Std. } \\
\text { Error } \\
\text { Mean }\end{array}$ \\
\hline \multirow{2}{*}{$\begin{array}{l}\text { ORGANIZATIONAL } \\
\text { CLIMATE }\end{array}$} & Gender & Male & $\begin{array}{l}12 \\
6\end{array}$ & 218.84 & 17.44 & 1.55 \\
\cline { 3 - 7 } & & Female & 95 & 215.52 & 15.23 & 1.56 \\
\cline { 2 - 7 } & $\begin{array}{l}\text { Type of } \\
\text { Manageme }\end{array}$ & Government & 99 & 214.56 & 15.54 & 1.56 \\
\cline { 2 - 7 } & Self & 12 & 219.73 & 17.08 & 1.55 \\
\hline
\end{tabular}




\begin{tabular}{|l|l|l|l|l|l|l|}
\hline & nt & Management & 2 & & & \\
\cline { 2 - 7 } & Locale & Urban & $\begin{array}{l}10 \\
0\end{array}$ & 216.16 & 15.97 & 1.59 \\
\cline { 3 - 7 } & & $\begin{array}{l}12 \\
1\end{array}$ & 218.45 & 17.05 & 1.55 \\
\cline { 3 - 7 } & \multirow{2}{*}{ Rural } & & & \\
\hline
\end{tabular}

From the table 3 it was observed that variation wise there was slight differences in the mean scores and standard deviation of each of the categorical variables. Therefore, it was thought obligatory to study the significance of difference between the two sub samples of each of the intra variables. Therefore, the independence sample test was adopted to find out the Levene's Test for Equality of Variances and ' $t$ ' test for equality of means. The result was presented in table 4.

\section{Table 4}

Independent Samples Test of Organizational Climate as Perceived by Teacher Educators_Male vs Female, Government vs Self Financed and Urban vs Rural

\begin{tabular}{|l|l|l|l|l|l|l|}
\hline \multirow{2}{*}{$\begin{array}{l}\text { ORGANIZATIONAL } \\
\text { CLIMATE }\end{array}$} & \multicolumn{2}{|l|}{$\begin{array}{l}\text { Levene's Test for Equality } \\
\text { of Variances }\end{array}$} & \multicolumn{2}{|l|}{ t-test for Equality of Means } \\
\cline { 2 - 7 } & $\mathrm{F}$ & Sig. & $\mathrm{t}$ & $\mathrm{df}$ & $\begin{array}{l}\text { Sig. } \\
\text { tailed) }\end{array}$ \\
\hline $\begin{array}{l}\text { Gender Variation } \\
\text { (Male vs Female) }\end{array}$ & $\begin{array}{l}\text { Equal } \\
\text { Variances } \\
\text { Assumed }\end{array}$ & 1.165 & .282 & $-1.481^{\#}$ & 219 & 0.140 \\
\hline $\begin{array}{l}\text { Type of Management } \\
\text { variation (Govt. vs Self } \\
\text { Financed) }\end{array}$ & $\begin{array}{l}\text { Equal } \\
\text { Variances } \\
\text { Assumed }\end{array}$ & 1.028 & 0.312 & $2.332 *$ & 219 & 0.021 \\
\hline $\begin{array}{l}\text { Locale variation } \\
\text { (Urban vs Rural) }\end{array}$ & $\begin{array}{l}\text { Equal } \\
\text { Variances } \\
\text { Assumed }\end{array}$ & 0.601 & 0.439 & $-1.021^{\#}$ & 219 & 0.308 \\
\hline
\end{tabular}

(*Significant at 0.05 level \& \# Not Significant at 0.05 level)

The analysis in table 4 shows that in case of Levene's Test for equality of variances the p values are $.282(p>0.05), 0.312(p>0.05)$ and 0.439 ( $p>0.05)$. So, that the variability in two conditions in all three cases are about the same, thus equal variances can be assumed. This table also shows that in case of comparing the organizational climate as perceived by teacher educators between male and female teacher educators the calculated $\mathbf{t}{ }_{(219)}$ value was 1.481 and $\mathrm{p}=0.140(\mathrm{p}>0.05)$ Hence, ' $\mathrm{t}$ ' was not significant at 0.05 level. So, $\mathbf{H}_{\mathbf{0}} \mathbf{1}$ was not rejected. In comparing the organizational climate as perceived by teacher educators between government and self-financed institutions the calculated $\mathbf{t}_{(\mathbf{2 1 9})}$ value was found 2.332 and $\mathrm{p}=0.021(\mathrm{p}<0.05)$. Hence, ' $\mathrm{t}$ ' was significant at 0.05 level. So, $\mathbf{H}_{\mathbf{0}} \mathbf{2}$ was rejected. The organizational climate as perceived by teacher educators between urban and rural institutions' teacher educators the calculated $\mathbf{t}_{(\mathbf{2 1 9})}$ value was found to be 1.021 and $\mathrm{p}=0.308(\mathrm{p}>0.05)$ Hence, $\mathrm{t}$ was not significant at 0.05 level. So, $\mathbf{H}_{\mathbf{0}} \mathbf{3}$ was not rejected.

\section{Testing Objective 4}

To fulfill this objective, the null hypotheses $\mathbf{H}_{\mathbf{0}} \mathbf{4}, \mathbf{H}_{\mathbf{0}} \mathbf{5}, \mathbf{H}_{\mathbf{0}} \mathbf{6}$ were formulated and tested.

\section{Testing Hypotheses $\mathrm{H}_{0} 4$ to $\mathrm{H}_{0} 6$}


Table 5

Group Statistics of Motivation to Work of Teacher Educators_Gender, Type of Management and Locale

\begin{tabular}{|c|c|c|c|c|c|c|}
\hline & Variations & & $\mathbf{N}$ & Mean & & \\
\hline $\begin{array}{l}\text { MOTIVATION } \\
\text { TO WORK }\end{array}$ & Gender & Male & $\begin{array}{l}12 \\
6\end{array}$ & 92.64 & 12.80 & 1.14 \\
\hline & & Female & 95 & 95.81 & 11.60 & 1.19 \\
\hline & $\begin{array}{l}\text { Type of } \\
\text { Manageme }\end{array}$ & $\begin{array}{l}\text { Governme } \\
\text { nt }\end{array}$ & 99 & 95.15 & 12.83 & 1.29 \\
\hline & & $\begin{array}{l}\text { Self } \\
\text { Manageme } \\
\text { nt }\end{array}$ & $\begin{array}{l}12 \\
2\end{array}$ & 93.07 & 11.96 & 1.08 \\
\hline & Locale & Urban & $\begin{array}{l}10 \\
0\end{array}$ & 94.47 & 11.72 & 1.17 \\
\hline & & Rural & $\begin{array}{l}12 \\
1\end{array}$ & 93.61 & 12.91 & 1.17 \\
\hline
\end{tabular}

From the table 5 it was observed that variation wise there was some differences in the mean scores and standard deviation of each of the different variation. Therefore, the independence sample test was adopted to find out the Levene's Test for Equality of Variances and ' $t$ ' test for equality of means. The result was presented in table 6.

Table 6

Independent Samples Test of Motivation to Work of Teacher Educators_Male vs Female, Government vs Self Financed and Urban vs Rural

\begin{tabular}{|l|l|l|l|l|l|l|}
\hline \multirow{2}{*}{$\begin{array}{l}\text { MOTIVATION TO } \\
\text { WORK }\end{array}$} & \multicolumn{2}{|l|}{$\begin{array}{l}\text { Levene's Test for Equality of } \\
\text { Variances }\end{array}$} & \multicolumn{3}{|l|}{ t-test for Equality of Means } \\
\cline { 2 - 7 } & $\mathrm{F}$ & Sig. & $\mathrm{t}$ & $\mathrm{df}$ & $\begin{array}{l}\text { Sig. } \\
\text { tailed) }\end{array}$ \\
\hline $\begin{array}{l}\text { Gender Variation } \\
\text { (Male vs Female) }\end{array}$ & $\begin{array}{l}\text { Equal } \\
\text { Variances } \\
\text { Assumed }\end{array}$ & 2.023 & 0.156 & $1.991^{*}$ & 219 & 0.050 \\
\hline $\begin{array}{l}\text { Type of } \\
\begin{array}{l}\text { Management } \\
\text { variation (Govt. vs } \\
\text { Self Financed) }\end{array}\end{array}$ & $\begin{array}{l}\text { Equal } \\
\text { Variances } \\
\text { Assumed }\end{array}$ & 0.579 & 0.447 & $1.248^{\#}$ & 219 & 0.213 \\
\hline $\begin{array}{l}\text { Locale variation } \\
\text { (Urban vs Rural) }\end{array}$ & $\begin{array}{l}\text { Equal } \\
\text { Variances } \\
\text { Assumed }\end{array}$ & 2.171 & 0.142 & $0.513^{\#}$ & 219 & 0.609 \\
\hline
\end{tabular}

(*Significant at 0.05 level \& \# Not Significant at 0.05 level)

The analysis in table 6 shows that in case of Levene's Test for equality of variances the palues are 0.050 ( $\mathrm{p}=0.05), 0.213$ ( $\mathrm{p}>0.05)$ and 0.609 ( $\mathrm{p}>0.05)$. So, equal variances can be assumed. This table also shows that in case of motivation to work of teacher educators between male and female teacher educators the calculated $\mathbf{t}_{(\mathbf{2 1 9})}$ value is 1.991 . Hence, ' $\mathrm{t}$ ' is significant at 0.05 level. So, $\mathbf{H}_{\mathbf{0}} \mathbf{4}$ was rejected. The motivation to work of teacher educators between government and self-financed institutions' teacher educators the calculated $\mathbf{t}_{(\mathbf{2 1 9})}$ value is 1.248 . Hence, ' $\mathrm{t}$ ' is not significant at 0.05 level. So, $\mathbf{H}_{\mathbf{0}} \mathbf{5}$ is could not be rejected. The motivation to work of teacher educators between urban and rural institutions' teacher educators the calculated $\mathbf{t}_{(219)}$ value is 0.513 . Hence, ' $t$ ' is not significant at 0.05 level. So, $\mathbf{H}_{\mathbf{0}} \mathbf{6}$ is could not be not rejected. 


\section{Testing Objective 5}

To fulfill this objective the following null hypothesis $\mathbf{H}_{\mathbf{0}} \mathbf{7}$ was formulated and tested.

\section{Testing Hypothesis 7}

Table 7

Correlation Matrix of Organizational Climate as Perceived by Teacher Educators and Teachers Educators' Motivation to Work

\begin{tabular}{|l|l|l|l|}
\hline \multicolumn{2}{|c|}{} & $\begin{array}{l}\text { ORGANIZATIONAL } \\
\text { CLIMATE }\end{array}$ & $\begin{array}{l}\text { MOTIVATION } \\
\text { TO WORK }\end{array}$ \\
\hline $\begin{array}{l}\text { ORGANIZATIONAL } \\
\text { CLIMATE }\end{array}$ & $\begin{array}{l}\text { Pearson } \\
\text { Correlation }\end{array}$ & 1 & $\mathbf{. 0 2 4}^{\#}$ \\
\cline { 2 - 4 } & Sig. (2-tailed) & & .728 \\
\cline { 2 - 4 } & $\mathrm{N}$ & 221 & 221 \\
\hline $\begin{array}{l}\text { MOTIVATION TO } \\
\text { WORK }\end{array}$ & $\begin{array}{l}\text { Pearson } \\
\text { Correlation }\end{array}$ & $\mathbf{. 0 2 4}^{\#}$ & 1 \\
\cline { 2 - 4 } & Sig. (2-tailed) & .728 & 221 \\
\cline { 2 - 4 } & $\mathrm{N}$ & 221 & \\
\hline
\end{tabular}

(\# not significant at 0.05 level of significance)

\section{Table 8}

Correlation Matrix of Teachers Educators' Motivation to Work and Dimensions of Organizational Climate as Perceived by Teacher Educators (Dimensions Abbreviated)

\begin{tabular}{|l|l|l|l|l|l|l|l|l|l|l|l|l|}
\hline \multicolumn{2}{|c|}{} & PS & CF & RS & R & CR & OS & ML & DMP & SS & W & IP \\
\hline $\begin{array}{l}\text { Motivation } \\
\text { to Work }\end{array}$ & $\mathrm{r}$ & .055 & -.020 & $\mathbf{. 1 7 3}^{* *}$ & -.002 & .050 & -.067 & -.066 & $\mathbf{. 1 5 8}^{*}$ & -.076 & -.052 & .077 \\
\cline { 2 - 13 }$($ MW) & $\mathrm{p}$ & .414 & .771 & $\mathbf{. 0 1 0}$ & .982 & .458 & .323 & .328 & $\mathbf{. 0 1 9}$ & .260 & .444 & .253 \\
\cline { 2 - 12 } & $\mathrm{N}$ & 221 & 221 & 221 & 221 & 221 & 221 & 221 & 221 & 221 & 221 & 221 \\
\hline
\end{tabular}

MW $=$ MOTIVATION TO WORK, PS= Performance Standard, $\mathrm{CF}=$ Communication Flow, RS = Reward System, $\mathrm{R}=$ Responsibility, $\mathrm{CR}=$ Conflict Resolution, $\mathrm{OS}=$ Organizational Structure, $\mathrm{ML}=$ Motivational Level, DMP= Decision Making Process, SS $=$ Support System, W= Warmth, IP = Identity Problem

$\mathrm{r}=$ Pearson Correlation, $\mathrm{p}=$ Sig. (2-tailed), $\mathrm{N}=$ total

The analysis in the table 7 shows that, correlation coefficient i.e. ' $r$ ' between score of Organizational Climate and Motivation to Work is .024. This indicates that a slight and positive correlation exists between Organizational Climate and Motivation to Work. The ' $p$ ' value is .728 ( $p>0.05)$ which is not significant at 0.05 level. Hence, $\mathbf{H}_{\mathbf{0}} \mathbf{7}$ is not rejected. So, it can be said that there existed positive but not significant relationship between Organizational Climate as perceived by teacher educators and teacher educators' Motivation to Work in Secondary level Teacher Education Institutions. Further analysis table 8 shows that only two dimensions i.e. Reward System (' $r$ ' value is .173 and 'p' value is 0.10 its less than 0.05) and Decision Making Process (' $r$ ' value is .158 and 'p' value is .019 its less than 0.05 ) are significantly correlated with motivation to work where as other dimensions have either very low or negative correlations with motivation to work. 


\section{Major Findings}

The study gave the following findings -

i) The status of organizational climate as perceived by teacher educators and level of motivation to work of teacher educators were not equally distributed in teacher education institutions.

ii) There was no significant difference in the status of organizational climate as perceived by male and female teacher educators' variations. However, from the mean scores it was revealed that the male teacher educators were high level than the female teacher educators.

iii) There was a significant difference in the status of organizational climate as perceived by govt. and self financed institutions teacher educators' variations. However, from the mean scores it was revealed that the self financed teacher educators were high level than the government teacher educators.

iv) There was no significant difference in the status of organizational climate as perceived by urban and rural institutions teacher educators' variations. However, from the mean scores it was revealed that the rural institutions teacher educators were more high level than the urban institutions teacher educators.

v) There was a significant difference in the level of motivation to work of male and female teacher educator's variation. However, from the mean scores it was revealed that the female teacher educators were highly motivated in their work than the male teacher educators.

vi) There was no significant difference in the level of motivation to work of govt. and selffinanced institutions teacher educator's variation. However, from the mean scores it was revealed that the govt. teacher educators were highly motivated in their work than the selffinanced teacher educators.

vii) There was no significant difference in the level of motivation to work of urban and rural institutions teacher educator's variation. However, from the mean scores it was revealed that the urban institutions teacher educators were highly motivated in their work than the rural teacher educators.

viii) There was no positive significant relationship between organizational climate as perceived by teacher educators and motivation to work of teacher educators.

\section{Conclusion}

Based on the analysis results can be presented some conclusions. First, the type of management variable influences the organizational climate of teacher education institutions. This revealed that teacher educators of self financed institutions differed significantly from their counter parts of government managed institutions. In respect of perception of organizational climate by the teacher educators of government and self financed institutions, significant differences in the status of perception were observed in the studies of Zahoor (2012), Akhiles (2013) and Shukla \& Pareta (2013). Secondly, the gender variable influences the teacher educators' motivation to work. The study was in conformity of the earlier studies undertaken by Saeed \& Muneer (2012) and Bhattacharya \& Mukherjee (2013). Others variables are not influenced on the organizational climate and motivation to work. Third, the organizational climate as perceived by teacher educators is not affected on their motivation to work. Thus, motivation to work was not an important factor affecting organizational climate. So, the head of the institutions and authorities should motivate the teacher educators so that they could sustain their motivation to work effectively and healthy organizational climate in their institutions. Hence the relationship between organizational climate and motivation to work could not be established. The study was also in conformity with earlier studies conducted by Bhattacharya \& Neogi (2006) and Russel (2014). 


\section{References:}

Akhilesh, A. (2013). A Comparative Study of Institutional Climate of Aided and Self- $\quad$ Financed Teacher Education Institutions, European Academic Research, Vol. I, pp.41- 46.

Bhattacharya, S. and Mukherjee, M. (2013). Organizational Climate and Work Motivation A study on Private sector organization. Indian Journal of Research, Vol. 2, Issue 1, pp. 136-138.

Bhattacharya, S. and Neogi, D.G. (2006). Goal settings tendencies, work motivation and organizational climate as perceived by the employees, Journal of the Indian Academy of Applied Psychology, Vol. 32, No. 1, pp. 61-65.

Chattopadhyaya, S. and Agarawal, K.G. (1976). Class, Culture and Organization. New Delhi: National Labour Institue.

Chattopadhyaya, S. and Agarawal, K.G. (2011). Organizational Climate Inventory $\quad\left(\begin{array}{lll}\text { Form } & B\end{array}\right)$, (OCI). Agra: National Psychological Corporation.

Davidson, E. (2007). The pivotal role of teacher in Tanzanian education. The Educational Forum, 71 (2), pp. 157-166.

Giri, V.N. \& Kumar, B.P. (2007). Impact of Organizational Climate on Job Satisfaction and Work Motivation. Psychological Studies, 52 (2), pp. 155-168.

Government of India. (2009). National Curriculum Frameworks on Teacher Education (NCFTE). National Council for Teacher Education (NCTE), New Delhi.

Government of India. (1949). Report of the University Education Commission, 1948-49. Ministry of Human Resource Development (MHRD), New Delhi.

Johnson, S. and Birkeland, S. (2003). The Schools that Teacher Choose, Keeping Good Teachers. pp. 20-24.

Kaur, R. \& Kaur, A. (2015). Organizational Climate relation to Professional Aspiration among teachers at Secondary stage. Edu-Research, Vol. 8, No. 8, pp. 56-62.

Khan, W.A. (2003). Teaching Motivation. New Delhi: Discovery Publishing House.

Ladyong, B.L. (2014). Organizational climate and teachers' work motivation: A case study of selected schools in Prachinburi. Thailand. Scholarly Journal of Education, $\quad$ Vol. 3 (5), pp. 5257.

Litwin, G.H. \& Stringer, R.A. (2001). Motivation and Organizational Climate. Boston: Division of research, Harvard Business School Press.

Mohanty, B. (2009). Organisational Climate and Leadership preference style of heads of institutions influencing academic performance at the secondary level of education in Orissa. Unpublished Ph.D. Dissertation, Utkal University, Odisha.

Pinder, C.C. (2008). Work motivation in Organizational Behavior. New York: Psychology Press.

Roy, K. (2015). Teacher educators' perception of the organizational climate of their own teacher education institutions. Unpublished M.Ed. Dissertation, Sikkim University, Sikkim.

Russel, J. J. (2014). Work Motivation of Secondary school Teachers in Relation to Organizational Climate, International Journal of Education and Psychological Research (IJEPR), Vol. 3, Issue 1, pp. 62-67. 
Saeed, A. and Muneer, R.( 2012). Work motivation of male and female secondary school teachers in Karachi. Interdisciplinary Journal of Contemporary Research in Business, Vol. 4, No. 6, pp. 462-467.

Shukla, H. and Pareta, A. (2013). A Study of Organizational Climate Perceived by the Employees of a Cooperative Dairy. Pacific Business Review International, Vol. 6, Issue 6, pp. 6-12.

Wiyono, B.B. (2016). Comparation of Teachers' Work Motivation Based on Gender, Age, Educational Level, Work Duration, Rank, and School Level, Journal of Education and Social Sciences, Vol. 3, pp. 61-66.

Zahoor, Z. (2012). A study of organizational climate and adjustment among private and government school teachers, Golden Research Thoughts, Vol. 1, No. 12, pp. 1-4.

http://www.ehow.com/facts_6951422_definition-work-motivation.html http://www. Shodhganga.inflibnet.ac.in/bitstream/10603/4491/8/08chapter\%202.pdf 